\title{
Divan şiirinde hançer çekmek
}

\section{Bahanur ÖZKAN BAHAR23o}

\begin{abstract}
APA: Özkan Bahar, B. (2020). Divan şiirinde hançer çekmek. RumeliDE Dil ve Edebiyat Araştırmaları Dergisi, (20), 402-XX. DOI: 10.29000/rumelide.791809.
\end{abstract}

\section{$\ddot{O} \mathbf{z}$}

Divan şiiri geleneği hemen hemen bütün unsurları önceden tayin edilmiş bir çerçeve içerisinde gelişir ve ilerler. Şair, kendisindeki ilhamı, yeteneği, hüneri hatta yaratıcılı̆̆ı belirli kalıplar içerisinde göstermeye çalışır. Geleneğin çok işlediği tema olan aşkta da durum farklı değildir. Âşığın, maşukun ve rakibin olduğu aşk üçgeninde herkesin rolü ve görevi bellidir. Maşuk yani sevgili yalnızca âşı/şair tarafından sevilmez; onun başka sevenleri de vardır. Bu durumdan cesaret alan sevgili âşı̆̆a/ şaire eziyet etmekten, canını acıtmaktan asla geri durmaz. Bunu yaparken en etkili silahlarını, gözünü, kaşını, kirpiklerini ve bakışını kullanır. Sevgiliye ait bu unsurlar kan akıtıcı, kesici, yaralayıcı olması bakımından ok, kılıç, hançer gibi aletlerle anılırlar. Bunlardan hançer sözcüğü müstakil olarak çokça kullanılmış hatta bazen kasidelere, gazellere redif olmuştur. Hançerin, diğer aletlere göre kolay taşınabilir olması, onu günlük hayatta da kullanılabilir yapmış ve bu durum şiirde de kullanılma oranını artırmıştır. Hançer sözcüğü şiirde sıklıkla kullanıldığı gibi; göz, kirpik, kaş gibi uzuvların kişileştirilerek kullanıldığı "hançer çekmek" tabiri içerisinde de yer almıştır. Genellikle bahsedilen kavramlarla anılmakla birlikte bakışın, kolun, insanın, ayın, padişahın "hançer çektiği” örneklere de rastlanmıştır. Hançerle ilgili kullanımların çok olması sebebiyle, çalışma, yalnızca "hançer çekmek" tabiri ile sınırlandırılmıştır.

Anahtar kelimeler: Divan şiiri, hançer, hançer çekmek

\section{Taking daggers in Divan poetry}

\begin{abstract}
Divan poetry tradition develops and progresses in a framework that has almost all elements determined in advance. The poet tries to show her inspiration, talent, skill and even creativity in certain patterns. The situation is not different in love, which is the theme that tradition works most. Everyone's role and duty is certain in love triangle with lover, beloved and opponent. Lover is not only loved by the lover / poet; she has other lovers. Encouraged by this situation, the beloved never hesitates to torment to hurt the lover / poet. In doing so, she uses her most effective weapons, eyes, eyebrows, eyelashes, and gaze. These lover's elements are remembered with tools such as arrows, swords and daggers in terms of being blood flowing, cutting, and hurt. Of these, the word dagger has been frequently used as a detached one, and sometimes has been used to the ode. The dagger is easy to carry compared to other tools and therefore it's functional in daily life, has increased the rate of its use in poetry. As the dagger is used detached in the poem; It was also frequently used in the term "to shoot dagger" in which limbs such as eyes, eyelashes, eyebrows are personalized. Although it is often referred to with the mentioned limbs, there are also examples of "to shoot dagger" of the gaze, arm,
\end{abstract}

230 Dr. Öğr. Üyesi, Burdur Mehmet Akif Ersoy Üniversitesi, Fen Edebiyat Fakültesi, Türk Dili ve Edebiyatı Bölümü (Burdur, Türkiye), bahanurozkan@gmail.com, ORCID ID: 0000-0002-1574-2694 [Makale kayıt tarihi: 23.06.2020-kabul tarihi: 20.09.2020; DOI: 10.29000/rumelide.791809] 
man, moon and sultan. The study is limited to the term "to shoot dagger" due to the large number of uses related to the dagger.

Keywords : Divan poem, dagger, shoot a dagger

\section{Giriş}

Divan şiiri geleneği içerisinde sevgilinin karakter özellikleri gibi fiziksel özellikleri de önceden tayin edilmiştir. Boyunun, saçının, gözünün, ağzının nelere benzeyebileceği gelenek içerisinde bilinmekte ve hepsinin çeşitli vazifeleri bulunmaktadır. Bunların içerisinde göz ve ona bağlı olarak kirpik, bakış ve kaş da genellikle kesici ve yaralayıcı aletlere teşbih olunmuştur. Çünkü Divan şiirinde maşukun asli görevi daima âşı̆̆ına cevr ü cefa etmek, onun acısını artırmaktır. Bu bakımdan sevgilinin gözü, kaşı, bakışı; oka, kılıca ya da hançere benzetilmiş ya da doğrudan bu sözcüklerle anılmıştır. Bu sözcüklerin ortak yanı kesici, yaralayıcı, can yakıcı hatta istenilirse can alıcı olmalarıdır.

Aşk hemen hemen bütün edebi geleneklerin en popüler temasıdır. Divan şiirinde aşk, genellikle âşık, maşuk, rakip üçlüsü arasında geçmektedir. Bu üçlünün hemen hemen tüm vasıfları gelenek tarafından belirlenmiştir. Bunlardan maşuk tüm fiziksel ve ruhsal hususiyetleriyle birlikte şahsına münhasır bir güzellik ve karakter arz etmektedir. Divan şiirindeki bir diğer önemli karakter olan âşı/şair daima maşukun vuslatına talip olur; ancak bu mümkün değildir. Şu halde bir tebessümüne, bakışına, merhametine hatta küçük bir ilgisine razıdır ve maalesef maşuk, âşı̆̆a bunları da asla göstermez. Bunları yapmadığı gibi âşı̆̆a eziyet etmekten, cefa etmekten asla imtina etmez. Biçare âşık bu eziyetleri bile maşukla olan alakanın devamı olarak gördügünden bunlara da razıdır ve kesilmesini istemez. Maşukun bu özellikleri birçok çalışmaya konu olmuştur.

Gelenek her ne kadar bir çerçeve ve kural dairesince ilerlese de sosyal hayatla ilgili her türlü imkândan da istifade eder. Kılıç, ok, şemşir, tîr, hadeng, tîg, nâvek, gibi silahlar da Divan şiirinde sıklıkla anlatı öğesi olarak kullanılır. Bu kavramlar genellikle maşukla ve onun uzuvlarıyla birlikte kullanılırlar. Fitne çıkaran, yaralayan, kan döken, rakipler arasında kavga çıkaran, bir bakışıyla can alan bir mahbubun bu tür silahları kullanması olağandır. Bunlardan hançer, kılıca göre daha kısa, genellikle ucu eğri ve sivri, kabzalı kesici silah demektir (Biber, 2005: 12).

Hançerin isimleri belirtilen silahlarla birlikte Divan şiirinde kullanıldığı belirtilmiştir. Bununla beraber ok, kılıç gibi silahlardan da bir miktar farklı bir görünüm arz etmektedir. Kılıca göre daha kısa ve hafif olması, ona daha kolay taşınabilme ve muhafaza edilebilme özelliği kazandırmıştır. Bu da diğer silahlardan farklı olarak ona günlük hayatta da kullanılabilme vasfı kazandırmıştır. Divan şiirinde hançer sözcüğü genellikle göz, kaş, kirpik ve bakış bağlamında ele alınmakla birlikte, bunların dışında da kullanımı olduğu tespit edilmiştir.

Fuzûlî ve Bâkî divanlarının karşılaştırması üzerine bir doktora tezi hazırlayan Aydın Yağcıoğlu, her iki divanda da kullanılan savaş aletlerinin kullanım oranlarını tablolaştıılmıştır. Bu tabloya bakıldı̆̆ında hançerin, Bâkî divanında tüm savaş aletlerinden daha fazla zikredildiği; Fuzûlî'de ise tîg ve oktan sonra en çok kullanılan savaş aleti olduğu görülmüsstür (Aydın Yağcığlu; 2009; 144). Tüm bunlara bakıldığında ve çalışma için tarama yapıldığında görülmüştür ki hançer, bu gelenek içerisinde adına en çok rastlanan savaş aletlerinden birisidir. Sadece Bâkî ve Fuzûlî Divanlarına bakıldığında bile yüzün üzerinde hançer sözcü̆ünün geçtiği görülmüştür. 
Sözcüğün gelenek içerisinde bu kadar yoğun kullanımı sözcükle ilgili birçok tamlama ve tabirin de ortaya çıkmasını sağlamıştır. Yapılan araştırmada hançerle ilgili olarak tespit edilen manzumelerde, hançer vurmak, hançer tutmak, hançere düşmek, hançer sunmak, hançerin üstüne atılmak, hançer dizmek, hançer göstermek, hançer atmak, sağlı sollu hançer takınmak, hançere düşmek, hançere sarılmak, hançer hançere gelmek, başına ok ve hançer yağmak; keskin hançer, altın hançer, çelik hançer, adaletsiz hançer, kasap hançeri, gaddar hançer, hançer-istân gibi çok muhtelif kullanımların olduğu görülmüştür.

“Divan Edebiyatında Şarap ve Şarapla İlgili Unsurlar” üzerine çalışma yapan Bahadır, gelenekte sarhoşun en belirgin özelliklerinden birisinin kavga etmesi olduğunu ve daima yanında dönemin meşhur silahı hançerle dolaştı̆̆ını söyler. Sarhoş kelimesinin geçtiği yerlerde hançer ve kan sözcüklerinin de kullandığını belirtmiştir. Konu ile ilgili verilen örneklerde sarhoşların ele hançer alması, kavga için iki yanına hançer bağlaması gibi kullanımların olduğu görülmüştür. (Bahadır, 2013; 80)

Hançerle ilgili belirtilen tabirlerden birisi de çalışmamıza konu olan "hançer çekmek" tir. Sevgilinin bizzat kendisi yaralayıcı, kan dökücü bir karakterdir. Yanında ise sevgilinin gözü, kaşı, kirpiği ve bakışı hançer ile anılır, aynı kavramlar kişileştirilerek tıpkı sevgilinin kendisi gibi "hançer çeken" varlıklar olarak karşımıza çıkar. "Hançer çekmek" ile ilgili yapılan taramalar da çok yaygın bir kullanımı olduğu görülmüştür. Hançerin şekli itibariyle kaşa benzemesi kaş ile anılmasına; ucunun sivri olması kirpik ve bakışlarla anılmasına; yaralayıcı, kan dökücü olması ise genel manada sevgili ile anılmasına olanak sağlamıştır. Bu kadar çok kullanılmasında, hançerin, hafif, taşınabilir, günlük hayatta kullanılabilir olmasının payı vardır.

"Hançer çekmek" tabirini ihtiva eden beyitlere bakıldığında birçok açıdan benzerlik arz ettikleri görülmüştür. Çalışma dikkat çekici örneklerle sınırlandırılmışır, sevgilinin, sevgilinin gözünün, kaşının, kirpiklerinin, bakışının hançer çektiği görülmüş ve ilgili beyitler bu başlıklar altında ele alınmıştır. Bunların dışında şairin, padişahın, sürahinin, Mirrih’in, gülün, sögütün, ayın hançer çektiği görülmekle birlikte sayıca diğerlerine göre çok azdır. Sevgili ve onunla anılan kavramların dışında hançer çeken diğer unsurlar da bir başlık altında ele alınmıştır. ${ }^{231}$

Sosyal hayatla ilgili her şey Divan şiirine konu olabildiği gelenekte savaş aletlerinin mühim bir yeri vardır. Zaman zaman gerçek anlamları ile kullanılan savaş aletleri sevgili ile alakalı olarak da kullanım alanı bulmuştur. Âşığına ezayı, cefayı kendisine iş edinmiş olan sevgili, vazifesini icra ederken elbette savaş aletlerine başvurur; ancak çoğu zaman uzağa gitmesine gerek kalmaz çünkü bu aletlerin çoğunu kendi bünyesinde barındırmaktadır. Bâkîden alının aşağıdaki beyitte, sevgili bakışı ile rakiplere hücum edebilmektedir zira bakışları hançer gibidir:

Agyâra kıldı hançer ile gamzesi hücûm

Küffâra çekdi tîgını san pâdişâh-ı Rûm

(Bâkî, G.326/1)

(Sevgilinin) bakışı ile hançerinin hücum etmesini görenler, Rum padişahının küffar üzerine kılıç çektiğini sanurlar.

\footnotetext{
231 Çalışmada, "hançer çekmek" ile ilgili kullanımlar belirli yüzyıl veya şair sınıflandırılması yapılmadan taranmıștır. Gazel $\mathrm{G}$, Kaside K ile gösterilmiştir. Herhangi bir gazel ya da kaside numarası ile gösterilmemiş beyitler ise şairlerin divanından değil mecmualardan alınmış olanlardır ve kaynakçada gösterilmiştir.
} 
Sevgili, âşı̆̆ına eziyet etmek için her yolu mubah görendir. Bu bakımdan eline geçen taş, sopa, kılıç, hançer, ok ne varsa istifade eder; bu durum bir şekilde âşığına alakasına dalalet ettiğinden âşık bunlardan şikâyet etmediği gibi bilakis memnundur:

Sitem taşı melâmet hançeri bî-dâd şem-şîri

Fuzûlî her cefâ kim gelse hoşdur câna cânândan

(Fuzûlî, G.212/7)

Ey Fuzûlî, sitem taşı, ayıplama hançeri, zulüm kılıcı gibi sevgiliden canına gelen her cefa hoştur.

Yukarıda verilen her iki beyitte de hançer sözcüğü yer almıştır. Aşağıda ise çalışmanın konusu olan "hançer çekmek" tabirinin yer aldığı beyitler bulunmaktadır.

\section{a. Sevgilinin hançer çekmesi}

Divan şiirinde maşukun yani sevgilinin vasıflarından konuyla ilgili olanlardan bahsedilmiştir. Gelenekte, genellikle hançer çeken sevgili olsa da bu görevin bazen gözüne, kaşına, kirpiğine ya da bakışına atfedildiği olmuştur. Bu başlık altında yer alan örnekler sevgilinin hançer çekme işini bizzat ifa ettiği örneklerdendir.

Sarhoş olan (sevgili) âşığına hançer çekmektedir. Âşık ise bunu bir cefa, eziyet, zahmet olarak görmediği gibi onun yaptığını bir zarafet olarak nitelendirmektedir:

Mest olup âşıka çeker hançer

Kâfirün itdigi zerâfeti gör

(Rûhî)

(Sevgili), sarhoş olup âşı̆̆ına hançer çekiyor, şu kâfirin yaptı̆̆ı inceliğe bak!

Şair, sevgili sözcüğünü çoğu zaman zikretmese de kullandığı çeşitli sözcük ve tamlamalarla sevgiliyi tanımlar. Bu beyitte alaycı sarhoş tamlamasıyla sevgiliyi kast etmektedir. Âşık, sevgilisi kucağını açtığında onun hançer çekeceğini zanneder, alışkın olduğu muamele budur çünkü. Fakat bu kez yanılmıştır, aslında sevgilinin kucağını açmasının sebebi kendisindeki altın kemeri göstermektir:

Değilmiş kasdı hançer çekmek ol ser-mest-i tannâzın

Hemân âgûş açup zerrin kemer göstermek istermiş (Nedîm, Kıta/1)

Alaycı sarhoşun kastı hançer çekmek değilmiş, kucağını açtığı zaman altın kemerini göstermek istermiş.

\section{b. Gözün hançer çekmesi}

Sevgilinin kendisinden başka gözü, kaşı, kirpiği ve bakışı da hançer çekmekte hatta bunlardan bazıları, bu işte sevgiliden daha ileri gidebilmektedir. Aslında kaş, kirpik, bakış da hançer çekse de bunların tamamı bir miktar göze bağlıdır, yani onun civarında ve onunla alakalıdır. Zira tespit edilen örneklerde en çok hançer çekenlerin başında göz ve bakış gelmektedir. Çalışmada her ikisinin de çokça örneği bulunması bakımından farklı başlıklar altında ele alınsa da bakış da gözle bağlantılıdır. Aşağıdaki beyitte şair kuşa benzeyen canını sevgilinin elinden kurtarmasının mümkün olmadığını çünkü iki kaşının doldurmasıyla gözlerinin ona hançer çektiğini söyler:

Halâs itmek elinden kuşca cânı nice mümkindür

İki ebrû kemânın toldurup hançer çeker gözler

(Ş. Yahyâ, G. 121/2) 
Kuşa benzeyen canımı elinden kurtarmak nasıl mümkün olsun, iki kaşın doldurduğu için gözlerin hançer çekiyor.

Şair, sevgilisine gözlerinin neden hançer çekip onu öldürmek istediğini sorduğunda, sevgilisi onları mazur görmesi gerektiğini çünkü her ikisinin de sarhoş olduğunu, söyler. Âşık, kendisine inansın diye de yemin eder:

Dedüm merdümlerün hançer çeküb cân kasdin eylerler

Dedi ma'zûr tut billâh ikisi dahi ser-hoşdur (Hayâlî Bey, G. 139/2)

Gözlerinin hançer çekip cana kast ettiklerini söylediğimde; (sevgili) onları sarhoş oldukları için mazur görmemi, istedi.

Gelenekte maşukun eziyet etmesi; âşığın da bu durumu eşine, dostuna, yaranına şikâyet edip dert yanması son derece doğaldır. Maşukun, âşı̆̆a eziyet etmesi için herhangi bir sebebe ihtiyacı yoktur. Bu beyitte suçunun ne olduğunu bilemeyen âşık, sevgilisinin sarhoş gözlerinin onu katletmek amaciyla hışımla hançer çekmelerinden yakınır ve dostlarına seslenir. Onlara, günahının ne olduğunu bilmediğini, söyler:

Dostlar bilsem günâhum neyledüm ol dil-bere

Hışm idüp mestâne çeşmi katlüme hançer çeker

(Figânî, G. 20/2)

Dostlarım, (keşke) sevgiliye ne yaptığımı, nasıl bir günah işlediğimi bilseydim; sarhoş gözleri bana kızıp öldürmek için hançer çekiyorlar.

Durumuna şaşıran bir diğer şair Tâci-zâde Cafer Çelebi ise sevgilisinin gözleri kendisini öldürmek amacıyla hançer çektiğinde Rabbine seslenir. Beyitte kendisini hasta olarak nitelendiren şair şaşkındır. Şaşılacak olan şudur ki kurban yani âşık tek olmasına rağmen onu öldürmek isteyenler yani gözler ikidir. Şair de bu durumda Rabbine seslenir, bunun nasl bir kurban ayini olduğunu bilmediğini, söyler:

Ben hastayı öldürmege hançer çekübdür gözleri

Yâ Rab bu ne âyîni ki kurbân bir ü kassâb iki (Tâci-zâde Câfer Çelebi, G. 243/6)

Ya Rabbi! Ben hastayı öldürmek için gözleri hançer çekerler, bu nasıl bir ibadet ki kurban bir iken kasabr iki tane.

Âşıkların gelenek içerisinde sevgiliye yalvarmaları, onlardan merhamet istemeleri hep rastlanılan durumlardır. Yine aşk acısından hastalanmaları, zayıflamaları, vücutlarında yaralar çıkması da hep görülen hadiselerdir. Bu beyitte şair bu minvalde hastalıklı bir görüntü arz etmektedir. Sevgilisinden, gözlerine kendisine hışımla hançer çekmemelerini söylemesini, kendisi hasta olduğu için kerem etmelerini, ister:

Hey di çeşm-i mestüye hışm ile hançer çekmesün

Hastedür gönlüm kerem kıl eyleme gavga yigit ～(Muîdî, G. 37/6)

Hey (sevgili)! Sarhoş gözlerine hışımla hançer çekmemelerini söyle. Bir yiğitlik yap, merhamet et, gönlüm hastadır çünkü.

Âşığın aşkı yolunda vazgeçemeyeceği hiçbir şey yoktur. Canı bile vazgeçebileceği şeyler arasındadır. Çünkü canı da dâhil olmak üzere maddi manevi neyi varsa hepsi sevgilisine aittir. Bu bakımdan sevgilisine seslenen şair, arzu ettiği şey canı ise onu teslim etmeye hazır olduğunu, bunun için gözlerinin hançer çekmesine ihtiyacı olmadığını, beyan eder: 
Ger murâdun cân ise gel sana teslim ideyin

Çekmesün şehlâlarun üstüme hançerler meded

(Muîdî, G. 63/3)

(Sevgili!) Şayet istediğin canımı almak ise gel sana teslim edeyim; ama medet eyle ki gözlerin üstüme hançer çekmesinler.

Aşağıdaki beyitte şair sevgilinin sarhoş gözlerinin kendisine hançer çekerek kan çıkarma çabası içerisinde olduğunu söyler. Bu işin yani gönül evini viran etme işinin onlara kalmadığını, onlara düşmediğini söyler. Çünkü sevgili bizzat kendisi bu işi hiç kimseye bırakmamaktadır:

Çeşm-i mestün niçe bir hançer çeküp kan eylemek

Sana mı kaldı gönül mülkini vîrân eylemek

(Muîdî, G. 229/1)

(Sevgili) Sarhoş gözlerin hançerini çekip kan çıkardiğı için gönlümü viran eyleme işi sana kalmamıştır.

Âşıkların ağlamaları, inlemeleri neredeyse onların vazifeleri gibidir. Bunun için de birçok sebepleri vardır. Sevgili, âşı̆̆a yüz vermediği gibi bununla yetinmez, bin türlü de eziyeti ona reva görür. Sürekli ağlayan, inleyen âşık, bir müddet sonra ağlayamamakta ve bu duruma şaşırmaktadır. Sebebini ise, sevgilisinin gözü kendisini öldürmek için hançer çekmesine bağlamaktadır. Bu durumu da büyücünün yağmur yağmaması için büyü yapmasına benzetir:

Aglamaz oldum gözün hançer çekelden katlüme

Sâhiri gör kim niçe sihr itdi yagmur olmasun

(Muîdî, G. 344/3)

Gözün beni öldürmek için hançer çektiğinden beri ağlamaz oldum. Büyücünün yağmur yağmasın diye nasıl bir sihir yaptı̆̆na bak.

Muîdî, başka bir beytinde yine aynı kavramları kullanır. Yukarıdaki beyitte istediği zaman yağmur yağmasına engel olabilen bir büyücüye benzetilen sevgili, aşağıdaki beyitte istediği zaman yağmur yağdırabilen bir büyücü olarak karşımıza çıkmaktadır. Her iki beyitte de hançer çeken sevgilinin gözleridir:

Gözlerün çekdükce gamzen hançerin kanlar döker

Her kaçan isterse bârân yagdurur câdû gibi

(Muîdî, G. 449/4)

Ne zaman gözlerin bakış hançerini çekerse, büyücünün yağmur yağdırması gibi kan döker.

Cem Sultan'a ait aşağıdaki beyitte sevgilinin gözleri evvela şairin gönlünü helak etmiştir. Bununla yetinmeyip bir de canının üstüne hançer çekmiştir. Şairin gönlünü helak ederek kan döken sevgilinin gözü, kan üstüne kan dökmek istediği için bu defa da âşı̆̆ın canı üstüne hançer çekmiştir:

Dil helâk idüp gözün hançer çeker cân üstine

Nice hûnîdür ki kan itmek diler kan üstine

(Cem Sultan)

Gözün, gönlümü helak eder ve canımın üstüne hançer çeker. Nasıl bir kan dökücü ki kan üstüne kan dökmek ister.

Muhibbî, sevgilinin gözünün hançer çekmesini dert etmez, diğer beyitlerde olduğu gibi şikâyet etmez. Sevgilinin gözleri hançer çekerek kanını dökse de gam değildir, çünkü şairin gönlü dudakları can bağışlayan bir sevgiliye düşmüştür. Gözleri can alsa da sevgilinin dudakları can bağışlama kudretine sahip olduğu için âşık canından olmayacaktır: 
Gözleri hançer çeküp kanlar dökerse gam degül

Lebleri cânlar bagışlar yâra düşdi gönlümüz

(Muhibbî, G.1341/2)

Sevgilinin gözleri hançerini çekip kan dökse dert edilmez; çünkü gönlümüz dudakları can bağışlayan bir sevgiliye düşmüştür.

Sevgili, şairin aklından, hayalinden, gözünün önünden hiç gitmez. Şair, bu durumu güzel bir teşbihle anlatır. Sevgilisi gözüne gelmiş bir misafir, gözü ise ev sahibidir. Şair, gözünü, kirpiklerini kıpırdatmaması hususunda uyarır, çünkü bu durum misafirin rahatsız olmasına sebebiyet verebilir. Bu da ev sahibi için edebe uygun bir davranış olmaz:

Hayâli gözdedir kirpiklerin depretme ey merdüm

Edeb şartı degil mihmâna çekmek mîz-bân hançer

(Fuzûlî, K.4/10)

Ey göz, (sevgilinin) hayali sende olduğu için kirpiklerini kıpırdatma, ev sahibinin misafire hançer çekmesi edebe uygun bir davranış değildir.

\section{c. Kaşın hançer çekmesi}

Divan şiiri geleneğinde sevgili müstesna bir güzeldir. Sevgilinin güzelliği, Nedîm'in beytinde olduğu gibi ülkeye, memlekete benzetilir. Sevgili de bu güzellik ülkesinin şahı, sultanıdır. Çok âşığı olan sevgili fitnecidir, bu memleket ve ülkelerde kavga çıkarır. Bu kavga çoğu zaman âşıları arasında olsa da zaman zaman kendi kaşı kendi kirpiği ile kavgaya tutuşabilmektedir. Bu beyitte sevgilinin kaşı kendisine yüz çevirmiş olan kirpiğe hançer çekiyor ve böylelikle güzellik ülkesinde yeni bir kargaşa çımış bulunuyor:

Kişver-i hüsne aceb âşûblar düşmüş yine

Çekmiş ebrû hançer ol ber-geşte müjgân üstüne

(Nedîm, K.2/21)

Kaş, kendisinden yüz çeviren kirpiğin üstüne hançer çekmiş. Acaba güzellik ülkesine yine ne kargaşalar düşmüş?

Kaş şekli itibariyle "ra", "dal” harflerine; yaya, kemana; zaman zaman da bu beyitte olduğu gibi hilale benzetilmiştir. Beyitte, sevgilinin kaşı hilale hançer çekmektedir. Çünkü hilal beyazlı̆̆ından, parlaklığından dolayı böbürlenmektedir. Bu durum tıpkı yukarıdaki beyitte olduğu gibi yeni bir kargaşaya sebep olacaktır; ancak kaşlar, hançeri çekip hilale hücum etmez. Şayet edecek olursa aslında ay kibrinden vazgeçecektir:

Râ kaşun hançer çeküp mâh-ı neve etse hücum

Terk ederdi anların bir dahı garrâlenmegi

(Beyânî, G. 815/3)

Ra kaşın hançer çekip hilale hücum etseydi, bir daha çalım satmaktan, böbürlenmekten vazgeçerdi.

\section{d. Kirpiğin hançer çekmesi}

Şekli itibariyle genellikle oka ve kılıca benzetilen sevgilinin kirpikleri aşağıdaki her iki beyitte de kişileştirilerek hançer çekmişlerdir. Zâtî’nin beytinde fitne çıkaran bu kez sevgili değil kirpikleridir. Sevgilinin kirpikleri hançerini çekip gözleri üzerine geldiğinde fitneyi uykusundan uyandırmıştır:

Zâtîyâ ol âfetün kirpükleri hançer çeküp

Gözi üzre geldi tâ fitne uyandı hâbdan

(Zâtî, G.1032/5)

Ey Zâtî! Sevgilinin kirpikleri hançerini çekip gözün üstüne geldiğinde fitne uykudan uyand. 
Sevgilinin her türlü eziyetine, cefasına razı olan âşık, canını almasına bile razıdır. Canını, âşığına hemen teslim etmeye hazırdır. Nitekim Helâkî aşağıdaki beytinde kan dökücü olarak nitelendirdiği sevgilisinin, kendisini katletmek amacıyla her köşeden çıkmasını arzu etmektedir:

Çıksa ol hûnî Helâkî katline her gûşeden

Tîg tartar gamzesi kirpikleri hançer çeker

(Helâkî, G. 50/7)

Helâkî, bakışı kulç̧; kirpikleri hançer çeken kan dökücü (sevgili), seni katletmek için keşke her köşeden çısa.

\section{e. Bakışın hançer çekmesi}

Bezm, Divan şiiri geleneği içerisindeki önemli mekânlardan birisidir. Bugün, içkili, sazlı, sözlü diyebileceğimiz dost meclisleri için kullanılan tabirlerden birisi de bezm-i mey'dir. Şarap meclisi anlamına gelen bu mekân hakkında âşı, sevgilisini uyarmaktadır. Şarabın olduğu bu mecliste herkes gibi sevgilinin bakışları da sarhoş olacaktır, şayet kan çıkarsa sevgili, sarhoş bakışları ile hançer çekmemelidir:

Bezm-i meydür güzelüm kan ola şâyed arada

Çekmesün hançerini gamzelerün mestâne (Bâkî, G. 437/3)

Güzelim, burası şarap meclisidir şayet arada kan olursa; sarhoş bakışların hançer çekmesinler.

Muîdî "hançer çekmek" tabirini çok kullanan şairlerden birisidir. Aşağıdaki beytinde sevgilisinin gözlerini kasaba benzeten şair kendisini de bayramlık kurbana benzetmiştir. Sevgilinin gözleri kasap olup hançer çekiyorsa âşığına da bayramlık kurban gibi yoluna canını feda etmek düşer:

Gamzeden hançer çeküp kassâb olalı gözlerün

Cân fedâ kıldum yolunda nitekim kurbân-ı ‘ ịd

(Muîdî, G. 61/2)

Gözlerinin yan bakışı kasap gibi hançer çektiğinden beri, ben de bayramdaki kurbanlık gibi onun yolunda cantmi feda ettim.

Zaman zaman kendisine hançer çekilmesinden hatta can talebinde bulunmasından hoşnut olan âşı, aşağıdaki beyitte bu durumun tersine sevgisinin bakışlarının sık sık kendisi üstüne hançer çekmemesini ister. Çünkü divane gönlünün o bakışın üstüne düşme ihtimali vardır, üstüne düştüğünde de kan çlkacaktır:

Çekme gamzen hançerin ikide bir cân üstine

Kim düşer dîvâne gönlüm ortada bir kan olur

(Muîdî, G. 76/3)

Bakışların ikide bir canımın üstüne hançerini çekmesin, ola ki divane gönlüm onun üstüne düşer ve böylece kan çlkar.

Bunca eza, cefa eden, fitne çıkaran güzelin Müslüman olamayacağı düşünüldüğünden olsa gerek Divan şiiri geleneğinde sevgili için kâfir, tersa gibi sözcükler sıklıkla kullanılır. Aşağıdaki beyitte, sevgili gibi kâfir olan onun gözleridir. Sevgilinin gözü bakış hançerini çekerek can mülkünü yıkmıştır; ancak kastı aslında âşı̆̆ın imanıdır:

Hey ne kâfirdür gözün kim gamzeden hançer çeküp

Yıkdı cân mülkin ser-â-ser kasdı imânumdadur

(Muîdî, G. 142/4)

(Sevgili), asıl kastı imanım olan gözlerin, nasıl bir kâfirdir ki bakışlarına hançer çektirip baştan ayağa can ülkemi yıkmıştır. 
15. yüzyılın önemli kadın şairi Mihrî Hatun "hançer çekmek" tabirini kullanırken sarhoş, hiddetli bir sevgili portresi çizer. Sarhoş sevgilinin gözü âşığa kızdıkça gamzesi de hançer çekmektedir. Âşsk, sarhoş elinde kalmanın ne kadar zor olduğundan dert yanar ve bu durumda sevgilinin elinde kılıç, bıçak olmasının çok tehlikeli olabildiğini söyler:

Çeşmi hışm itdükçe câna gamzesi hançer çeker

Mest elinde dostlar kllıç biçag olmak ne güç

(Mihrî, G. 11/4)

Gözleri eziyet ettikçe gamzesi de hançer çeker. Dostlarmm sarhoş elinde kılıç, bıçak olmak çok zordur.

Rüstem ve Kahraman Divan şiirinde adına çokça telmih yapılan Acem mitolojisinin önemli iki şahsıdır. Kasidelerde övülmek istenen devlet adamı güç ve kahramanlık bakımından bu şahıslarla kıyaslanır ve genellikle övülen devlet adamının ondan bile üstün olduğu ileri sürülür. Bu beyitte şair, sevgilinin bakışının kudretini anlatmak için bu iki kahramanı kullanmıştır. Sevgilinin gözünü Kahraman’a benzeten şair, savaş zamanında onun kılıcı ve hançerinin korkusundan Rüstem’in bile ona yaklaşamayacağını söylemiştir:

Gamzelerden tîg u hançer çekse kasd-ı âşıka

Rüstem irmez Kahramân-ı çeşmüne rûz-ı mesâf

(Bâkî, Kita,6/1)

Savaş zamanı, aşı̆̆ı öldürmek kastıyla gamzeler kılıç ve hançerini çektiğinde, gözünün Kahraman'ma Rüstem yaklaşamaz.

Bakışın sarhoş ve kan dökücü olması mazmunu bu beyitte de karşımıza çıkmaktadır. Sevgilinin bakışlarının hançerini çekip sarhoş sarhoş bakmaktadır. Sarhoş olan ve elinde hançeri bulunan sevgili âşı̆̆ının kanını su gibi dökmezse buna şaşılır:

Çeküp hançerlerin gamzen bakar mestâne mestâne

Acebdür yire dökmezse bir içim su gibi kanum

(Muîdî, G. 291/4)

Bakışların hançerini çekmiş sarhoş sarhoş bakıyor. Kanımı, bir içim su gibi yere dökmezse şaşarım.

Sevgili gibi gözleri, bakışları da büyücü, cadı olabilir ve fitne çıkarabilir. Şair, sarhoşçasına göz ucuyla naz edip aynı zamanda hançer çekebilen bir sevgiliyi daha önce görmediğini, söyler:

Göz ucuyla nâz ider mestâne hem hançer çeker

Görmedim ol gamze-i câdû gibi fettân mest

(Nefí, G. 28/2)

Sevgilinin bakışları sarhoş gibi göz ucuyla naz ederken bir yandan da hançer çeker. O büyücü bakışlar gibi fitne çıkaranın görmedim.

Cem Sultan yirmi beyitlik yek-âhenk gazelinde güzellerin özelliklerini sıralamıştır. Şair, sarhoş ve şaşkın bir şekilde gezerken güzellik bağında açmış iki taze gonca görmüş ve her bir beyitte bunların vasıflarını sıralamıştır. Şair, güzelleri, yüzleri, kokusu, boyları, dudakları, saçları, benleri ile övmüştür. Bunun yanında birinin kirpiklerinin ok attığından; diğerinin bir bakışıyla âşıklarına bin hançer çektiğinden bahsetmiştir:

Birinün müjgânı tîri âleme nâvek-figen

Birinün bir gamzesi uşşâka bin hançer çeker (Cem Sultan, G. 115/10)

(Maşuklarm) Birinin kirpikleri kılıcı âleme ok atar, birinin bir bakışı âşıklara bin hançer çeker. 
Hançerle birlikte çok zikredilen sözcüklerden birisi kurbandır. Kasap sevgili ya da onunla ilgili bazı kavramlar; kurban ise âşık ya da âşıklarıdır. Sevgilinin bakışları hançerini çekerek âşıklarını kurban etmektedir. Sevgilinin cellada benzeyen gözleri, şairin daha önce gördüğü hiçbir kasaba benzememektedir:

Gamzesi hançer çeküp âş̧ıların kurbân ider

Çeşm-i cellâdına hiç kassâb benzer benzemez

(Muhibbî, G.1304/2)

(Sevgilinin) Bakışı hançer çekerek âşıklarımı kurban etse de cellat gözlerine hiçbir kasap benzemez.

Beyânî aşağıdaki beytinde ilk dizede gamze, ikinci dizede nigâh sözcüğünü kullanarak sevgiliye ait bu özelliği farklı kavramlar gibi ele almaktadır. Sevgilinin sarhoş bakışları o kadar kan dökücüdür ki kendisinde bir miktar merhamet bulunan nigâha bile hançer çeker:

Beyânî gamze-i ser-mesti ol kadar hûnî

Nigâh-ı merhamet-âlûdına çeker hançer

(Beyânî, G. 122/5)

Beyânî, (sevgilinin) sarhoş bakışı o kadar kan dökücü ki (sevgilinin) merhametli bakışına bile hançer çeker.

Sinem nîzelerin ol müjeler togrıldur

Üstüme hançerin ol gamze-i mestâne çeker

(Bâkî, K.12/6)

(Sevgilinin) kirpikleri göğsüme mızrakların doğrultuyor, o sarhoş bakışl üstüme hançerini çekiyor.

\section{f. Diğer unsurların hançer çekmesi}

Yukarıdaki örneklerde görüldüğü gibi hançer sözcüğü ve buna bağlı olarak kullanılan hançer çekmek tabiri genellikle sevgili ve onunla ilgili kavramlarla birlikte kullanılmaktadır. Bunun dışında aşağıdaki beyitlerde ise sırasıyla gülün, Mirrih'in, söğütün, şairin, sürahinin, Ay’ın, padişahın hançer çektiği örneklere yer verilmiştir.

Divan şiiri geleneği içerisinde genellikle sevgili ve ona ait unsurların hançer çektiği görülse de aşağıdaki ilk örnekte gül, dikenini, hançer gibi kullanarak çekmektedir. Şair, hatmi, nilüfer, gül ve susamın olduğu bahçeyi bir savaş meydanı gibi tasvir etmiştir. Hatmi elinde mızrak tutarken, nilüfer siper almış, gül bedeninde bulunan dikenden hançer yapıp onu çekmiş ve susam da eline kılıç almıştır:

Hatmi tutmuş nize nilüfer ele almış siper

Hârdan hançer çeker gül süsen olmuş tîg-zen (Tâci-zâde Câfer Çelebi, K. 11/12)

Hatmi mızrak tutmuş, nilüfer siperi eline almış, gül dikenden hançer çekerken susam ise kılıç kullanmaktadir.

Aşağıdaki beyitte, bir kasapmış gibi hançer çeken Mirrih'tir. Mirrih, sevgili için bir koç kurban etmek istemiş ve hançeri bu amaçla çekmiştir:

Geldi Mirrih üstine hançer çeküp kassâbvâr

Berre-i çarhı diler kim ide kurbânun senün

(Tâci-zâde Câfer Çelebi, Kıta, 5/3)

Mirrih, koçu, senin için kurban etmek istediğinden, üstüne bir kasap gibi hançerini çekerek geldi. 
Daha önceki beyitlerde, güneşe, sevgiliye benzemeye çalışıyor diye hançer çekildiği görülmüştür. Hançer çekmek için benzer bir mazeret aşağıdaki beyitte bulunmaktadır. Şairin kendisine seslendiği beyitte, gökyüzünde gördüğünün bir göktaşı olmadığını, hilal, sevgilinin yüzüne benzemeye çalıştığından dolayı Mirrih’in, ona kızarak hançer çektiğini, söyler:

Bâkiyâ gökde şihâb atılmadı Mirrih-i çarh

Rûy-1 yâre öykünür diyü mehe hançer çeker

(Bâkî, G. 183/7)

Ey Bâkî! Gökyüzünden taş atılmadı. Göğün Mirrihỉ, yârin yüzüne benzemeye çahşıyor diye aya hançer çekiyor.

Aşağıdaki beyitte doğaya ait unsurlardan su ve söğüt kişileştirilmiştir. Su asker gibi zırh giymiş, söğüt ise hançer çekmiştir:

Devr-i güldür münhezim kılmaga tevbe leşkerin

Giydi Dâvûdî zirihler âb u hançer çekdi bîd

(Muîdî, G. 59/3)

İlkbahar mevsimi geldiğginde tevbe ordusunu bozguna uğratmak için su Hz. Davut’unki gibi zırhlan giyindi, söğüt ise hançer çekti.

Çalışma için derlenen beyitler arasında "hançer çekmek" tabiri geçmesine rağmen olayın vuku bulmadığı yani hançerin çekilmediği iki beyitten birisi aşağıdakidir. Tabirin geçtiği diğer beyitlerde hançer çekilmiş, can almaya kasetmiş ya da arada kan çıkmasına sebebiyet vermiştir. Yine tabirin geçtiği diğer beyitler, okuyucuda kavga ya da savaş ortamı hissiyatını uyandırmaktadır. Aşağıdaki beyitte ise tam tersi bir sulh ortamı hâkimdir. Sevgilinin gamzesinin devrinde kimse kimseye hançer çekmez ve şair sevgilisinin kolunu boynuna dolar:

Devr-i ġamzende senün kimseye hançer çekmez

Boynuma alurın ey şûh-ı dil-ârâ kolun ～(Bâkî, 267/3)

Ey şuh sevgili, senin gamzenin döneminde kimseye hançer çekmez, kolunu boynuma alırm.

Sevgili ve sevgili ile ilgili kavramların dışında, hançer çekenlere bakıldığında, bu eylemi gerçekleştirme sebeplerinin bazılarında kıskançlık olduğu görülür. Benzer şekilde hançer çekilmesinin sebebi aşağıdaki beyitte de kıskançlıktır. Beyitte geçen sürahi sözcüğü, aslında tüm içkiyi içerisinde ihtiva etmesi bakımından kadehten üstün gibi görünmektedir; ancak kadeh sürahinin yapamadığını yapmakta yani sevgilinin dudaklarına o ulaşmakta, dudaklarında o dolaşmaktadır. Bu duruma kızan sürahi de kadehin üstüne hançerini çeker:

Bûs-ı dehân yâre tolaşır diyü müdâm

Hançer çeker sürâhî gelüp sâgar üstüne

Sevgilinin dudağının öpücüğüne daima dolaşıyor diye sürahi kadehin üstüne hançer çeker.

Daha önceki beyitlerde ay ve güneş, sevgiliye benzemeye çalıştıkları için kendilerine hançer çekilmesine maruz kalmışlardı. Bu beyitte ise sevgilinin boyu ve yürüyüşü bakımından kendisine benzetildiği servi, sevgilinin boyu ile davaya tutuştuğundan söğüt kendisine hançer çekiyor:

Serv ḳaddüñ ile da‘vā eylemiş

Bīd işidüp yüzine hançer çeker

(Muhibbî, G.1031/2)

232

Bâkî Divanında ilgili beyit yerinde başka bir beyit bulunmaktadır. Bu beyit Milli Kütüphane o6 HK 319/1 No’lu Şiir Mecmuasında geçmektedir.

Adres

Kırklareli Üniversitesi, Fen Edebiyat Fakültesi, Türk Dili ve Edebiyatı Bölümü, Kayalı Kampüsü-Kırklareli/TÜRKIYYE e-posta: editor@rumelide.com 
Servi ağacı boyun ile davaya girişti diye söğüt onun yüzüne hançer çekiyor.

Güneş ve ay parlak varlıklardır. Bundan dolayı da Divan şiirinde sevgili, sevgilinin yüzü, yană̆ ay ve güneşe benzetilir. Bu beyitte güneşin doğal parlaklığı, gerçek sebebi dışında, sevgiliye benzeme çabasına bağlanmıştır. Güneşin, cihanı aydınlatan sevgiliye öykünmesi hilali kızdırmıştır ve hilal güneşin üzerine hançer çekmiştir:

Niçün ol hûrşîd-i âlem-tâba öykündün diyü

Mâh-ı nev hançer çeker mihr-i dırahşân üstüne

(Bâkî, G. 13/3)

Hilal, niçin âlemi aydınlatan güneşe (sevgiliye) benzemeye çalışıyorsun diye, güneşin üstüne hançer çeker.

"Hançer çekmek” tabiri kullanılmasına rağmen fiziksel olarak gerçekleşmediği beyitlerden bir diğeri aşağıdakidir. Ancak beyitte fiziksel olarak hançer çekilmese de gerçekleşecek olduğunda bu işi yapacak olan dönemin padişahıdır. III. Ahmet’in Rusya ile girdiği Prut savaşında galip gelmesi, Divan şiirinde Nâbî, Kâmî, Sabit gibi birçok şairin manzumelerine konu olmuştur. Prut savaşında, galibiyet için birkaç girişimde bulunan Rus ordusu, sayıca kendilerinden üstün olan Osmanlı ordusuna karşı başarı kazanamamış ve bunun üzerine sulh teklifinde bulunmuşlardır. Osmanlı ordusunun taarruz hazırlı̆̆ında bulunduğu bir esnada yapılan sulh teklifi ve varılan anlaşma, dönemin şairi Sabit’in şiirine yansımıştır. Zamanın padişahı III. Ahmet’e yazdığı kasidesinde, padişahın kılıç ve hançer çekmeden Rus ordusunu dağıttığını söylemiştir:

Bir teveccühle tagıtdı Moskovun cem'iyyetin

Tîg ü hançer çekmeden kutb-ı zafer-yâver gibi

(Bosnalı Sabit, K. 43/21)

Kendisine zaferin yardım ettikleri gibi kılıç ve hançer çekmeden bir teveccühle Rus ordusunu dağıttı.

Fuzûlî Divanının dördüncü kasidesi, ikinci ve üçüncü de olduğu gibi Hz. Peygamber için yazılmış naat türünde bir manzumedir. Kasîde Der Medh-i Hazret-i Fahr-i Kâinat başlıklı hançer redifli naatın aşağıdaki beytinde, ayın her ay hilal şeklinde olmasını Hz. Peygamberin düşmanını katlemek amacıyla hançer çekmesine, bağlar:

Adû-yı câhınun kat'-ı hayâtiyçün çeker her ay

Gılâf-ı lâciverdîden hilâl-i âs-mân hançer

(Fuzûlî, K. 4/19)

Gökyüzünün hilali, senin düşmanlarını hayatın sona erdirmek için her ay lacivert kılıfindan hançer çeker.

\section{Sonuç}

Sosyal hayatın tüm imkânlarından istifade eden Divan şiirinde savaş aletlerinin önemli bir yeri vardır. Bunların başında ise kılıç, ok, yay ve hançer gelmektedir. Hançer şekli itibari ile sevgilinin kaşına, gözüne, kirpiğine benzetilmektedir. Aynı zamanda yine kan dökücü, öldürücü, yaralayıcı olması bakımından bu kavramlarla ve sevgilinin bakışı ile anılmaktadır. Bu özelliklerinin dışında hançerin diğerlerine oranla daha rahat taşınabilir olması günlük hayatta kullanım alanını artırmış, bu oran Divan şiirinde kullanımına da yansımıştır. Hemen her divanda kılıç ve ok ile yarışır durumdadır; hatta bazı divanlarda ise ikisinden de fazla kullanılmıştır. Hançer sözcüğünün bu kullanım sıklı̆̆ hançer çekmek adlı bir tabirin de divanlarda yer almasını sağlamıştır. 
Hançer sözcüğü sadece bir divanda bile onlarca kez kullanılmaktadır. Bu bakımdan çalışmanın geçerliliği adına, divanlarda yer alan "hançer çekmek" tabiri ile tarama yapılmış ve ilgili beyitler değerlendirmeye alınmıştır. "Hançer çekmek" tabiri ile ilgili herhangi bir sınıflandırmaya gidilmeden tarama yapılmıştır.

"Hançer çekmek" tabiri tıpkı hançer sözcüğünde olduğu gibi genellikle sevgili ile alakalı olarak kullanılmıştır. Sevgilinin tıpkı kendisi gibi yaralayıcı, can yakıcı, kan dökücü olan gözleri, kaşları, kirpikleri ve bakışları hançer çekebilmektedir. Tespit edilen kırk örnekten otuz tanesinde hançer çeken sevgili, sevgilinin gözleri, kaşları, kirpikleri ve bakışlarıdır. Diğer on beyitte hançer çekenler ise ikişer beyitte Mirrih, söğüt, hilal; birer beyitte ise sürahi, gül ve padişahtır. Bâkî̀ye ait beyitte ise diğer beyitlerin aksine tam bir sükûnet ortamı hâkimdir ve bu ortamda kimse hançer çekmemektedir. Görülen odur ki rastgele seçilen beyitlerin büyük çoğunluğunda hançer çeken sevgili bizzat kendisi ya da onunla ilgili kavramlardır.

Sevgili ve onunla ilgili kavramların hançer çektiği otuz beyte kendi içerisinde bakıldığında sevgilinin bizzat kendisinin hançer çektiği beyit sayıcı yalnızca ikidir. Yine sevgilinin kaşının ve kirpiklerinin hançer çektiği beyitlerin sayısı ikidir. Gözlerin hançer çektiği beyit sayısı ise on ikidir. Bakışlar ise on dört beyitle en çok hançer çeken kavram olmuştur.

Sevgiliden ve onunla ilgili kavramların hançer çektiği beyitlerde dikkat çeken bir özellik de kullanılan sözcük ve tamlamalardır. Gerek sevgilinin gerekse onu ait unsurların hançer çektiği beyitlerde mest, mestâne, ser-hoş, ser-mest sözcüklerinin yoğun kullanımı dikkat çekmektedir. Hançer çekenin bizzat sevgilinin kendisi olduğu her iki beyitte de bu sözcükler kullanılmıştır. Her iki beyitte de sevgili sarhoş olduğu bir anda hançer çekmiştir. Sevilinin gözlerinin ve bakışlarının hançer çektiği beyitlerde de durum farklı değildir. Bu beyitlerde kullanılan ser-hoş gözler, mestâne çeşm, çeşm-i mestâne, çeşm-i mest, mestâne gamzeler, gamze-i ser-mest, gamze-i mestâne, gamzenin mestâne mestâne bakması gibi tamlama ve tabirler dikkat çekicidir. Sevgili ve onunla ilgili kavramların hançer çektiği otuz beyitte sarhoş ve benzer ifadelerin kullanıldığı beyit sayısı on ikidir. Hilal, söğüt, gül gibi muhtelif varlıkların hançer çektiği on beyitte ise ser-hoş, ser-mest, mest, mestâne gibi herhangi bir ifadeye rastlanmamıştır.

Hançer çekmek tabirinin geçtiği beyitlerde dikkat çeken bir diğer özellik de şudur ki beyitler, okuyucuda bir kavga ya da savaş ortamı izlenimi yaratmaktadır. Hançerin kesici, yaralayıı bir alet olması ve bu aletin sahibi tarafından çekilmiş olması bu izlenimin başlıca müsebbibi olsa da kullanılan diğer sözcük, tamlama ve deyimlerin de anlatımın pekiştirilmesinde önemli bir rolü vardır. Tabirin geçtiği beyitlerin birçoğunda katletmek, öldürmek gibi eylemin doğrudan zikredildiği görülmektedir. Bunların dışında cana kast etmek, cana hançer çekmek, can mülkünü yıkmak, can üstüne hançer çekmek, aşığa kast etmek, su gibi kanını yere dökmek, hayatı kat etmek, kan dökmek, kan eylemek, kan etmek, kan almak, kan olmak; can teslim etmek, yoluna can feda kllmak gibi öldürmek eylemini anlatan deyimlere yer verilmiştir. Bir şekilde kan dökülmesini yani ölümü hatırlatan tabirlerin geçtiği beyitlerin sayısı yirmi üçtür ki "hançer çekmek" tabirinin geçtiği beyitlerin yarısından fazlasında bulunmaktadır.

Hançer çekilen beyitlerde tespit edilen diğer bir hususiyet de hançer çeken sevgili ya da sevgiliye ait kavramların kanla ilgili sözcüklere paralel olarak hûnî, kasap, cellat sözcükleri kullanılırken; âşık içinse kurban sözcüğ̈̈nün kullanılmasıdır. 
Bâkî’nin, sevgilinin bakışının zamanında hiç hançer çekilmediğini söylediği beyit ve III. Ahmet'e yazılan kaside beyti dışında, tabirin geçtiği beyitlerin hemen hemen hepsinde bir kavga ya da savaş ortamı hâkim iken sadece zikredilen iki beyitte tam tersi sulh ortamı vardır.

Çalışma ile ilgili yapılan taramalarda görülmüştür ki gerek "hançer" sözcüğü gerekse "hançer çekmek" tabiri Divan şiiri geleneğinde sıklıkla kullanılmıştır. "Hançer çekmek" tabirine Fuzûlî, Bâkî, Bosnalı Sabit, Muhibbî, Muîdî, Tâci-zâde Cafer Çelebi, Beyânî, Cem Sultan, Nefî, Mihrî Hatun, Ruhî, Şeyhülislam Yahyâ, Hayâlî, Figânî, Nedîm, Helâki ve Zâtînin şiirlerinde rastlanmıştır. Tabiri en çok kullanan şairler ise Muîdî ve Bâkî'dir.

\section{Kaynakça}

Ak, C. (2006). Muhibbî Divanı İzahlı Metin I. Cilt. Trabzon : Trabzon Valiliği.

Akkuş, M. (1993). Nefi Divanı. Ankara : Akçă̆.

Aydın Yağcıŏ̆lu, S. (2009). Fuzûlî ve Bâkî Divanlarının Karşılaştırılması (Yayımlanmamış Doktora Tezi). İstanbul : İstanbul Üniversitesi Sosyal Bilimler Enstitüsü.

Bahadır, S. C. (2013). Divan Edebiyatında Şarap ve Şarapla İlgili Unsurlar. İstanbul : Kitapevi.

Başpınar, F. (2008). 17. Yüzyıl Şairlerinden Beyânînin Divan’’ (Yayımlanmamış Doktora Tezi). İstanbul : Marmara Üniversitesi Türkiyat Araştırmaları Enstitüsü.

Bellibaş, A. (2014). Milli Kütüphane o6 HK 319/1 No'lu Şïr Mecmuası (İnceleme-Metin-Dizin), (Yayımlanmamış Yüksek Lisans Tezi). Adıyaman: Adıyaman Üniversitesi Sosyal Bilimler Enstitüsü.

Biber, H. (2005). Urartu Silahları: Kılıç, Hançer ve Bıçaklar, (Yayımlanmamış Doktora Tezi). Van : Yüzüncü Yll Üniversitesi Sosyal Bilimler Enstitüsü.

Çalışkan Aydemir, N. (2019). Hurûf-ı Hecâ Üzre Mürettep Şïr Mecmuası (İnceleme-Metin). (Yayımlanmamış Yüksek Lisans Tezi). Bursa : Uludağ Üniversitesi Sosyal Bilimler Enstitüsü.

Çavuşoğlu, M. (1982). Helâkî Dîvan (Tenkidli Basım). İstanbul : İstanbul Üniversitesi.

Çavuşoğlu, M-Tanyeri, M. A. (1987). Zâtî Divanı Gazeller Kısmı III. Cilt. İstanbul : İstanbul Üniversitesi Edebiyat Fakültesi.

Karacan, T. (1981). XVII. yy. Şairlerimizden Sabit ve Edisiyon Kritikli Divan Metni (Yayımlanmamış Yüksek Lisans Tezi). Erzurum : Atatürk Üniversitesi Sosyal Bilimler Enstitüsü.

Macit, M. (1997). Nedim Divanı. Ankara : Akçă̆.

Tarla, A. N. (1945). Hayâllı Bey Dîvânı. İstanbul: İstanbul Üniversitesi Edebiyat Fakültesi.

Tanrıbuyurdu, G. (2012). Muî̀î Dîvân (Metin-Çeviri) (Yayımlanmamış Doktora Tezi). Kocaeli : Kocaeli Üniversitesi Sosyal Bilimler Enstitüsü. 